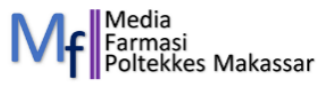

\title{
PENETAPAN KADAR VITAMIN C PADA BUAH JAMBU BIJI MERAH (Psidium guajava L.) DENGAN METODE TITRASI NA-2,6 DICHLOROPHENOL INDOPHENOL (DCIP)
}

\author{
Septipianus Arung Padang*), Rasnita Maharani Maliku*) \\ ${ }^{*}$ Akademi Farmasi Toraja \\ *) E-mail korespondensi : arunkcakep@yahoo.com
}

DOI: https://doi.org/10.32382/mf.v13i2.879

\section{ABSTRAK}

Buah Jambu biji merah (Psidium guajava L.) mengandung beberapa senyawa fitokimia serta vitamin $\mathrm{C}$ yang berfungsi sebagai antioksidan. Tujuan penelitian ini adalah untuk menganalisis kandungan vitamin $\mathrm{C}$ dengan metode analisis kualitatif dan metode analisis kuantitatif. Sampel yang digunakan untuk analisis kualitatif adalah Buah Jambu biji merah mentah, setengah matang, dan matang dengan penambahan larutan pereaksi tembaga (II) sulfat $0,5 \%$, besi (II) sulfat 0,2 N, larutan $\mathrm{NaOH}$ 0,1 N dan larutan Na-2,6 dichlorophenol indophenol (DCIP) $0.5 \mathrm{mg} / \mathrm{ml}$. Hasil yang diperoleh adalah sampel Buah Jambu biji merah (Psidium guajava L.) positif mengandung vitamin C dengan adanya reaksi warna yang terjadi saat penambahan larutan pereaksi. Penetapan kadar vitamin $\mathrm{C}$ yang terdapat dalam Buah Jambu biji merah (Psidium guajava L.) dilakukan dengan metode titrasi yang menggunakan Na-2,6 dichlorophenol indophenol (DCIP) sebagai titran. Berdasakan penelitian ini diperoleh kadar vitamin C pada Buah Jambu biji merah (Psidium guajava L.) sebesar 0,429 mg/ gram atau 42,9 mg/ 100 gram.

Kata kunci : Jambu biji merah (Psidium guajava L.), Analisis kualitatif, Analisis kuantitatif, vitamin C

\section{PENDAHULUAN}

Radikal bebas merupakan senyawa oksigen yang reaktif, secara umum diketahui sebagai senyawa yang memiliki elektron yang tidak berpasangan. Reaktivitas radikal bebas dapat dihambat oleh sistem antioksidan yang berperan dalam sistem kekebalan tubuh. Radikal bebas dapat terbentuk sebagai hasil proses metabolisme alami tubuh yang merupakan sumber endogen, seperti respirasi mitokondria, efek samping dari metabolisme kimia, peradangan akibat kerja fisik, olahraga berlebihan, reaksi terhadap besi dan logam lain, serta makanan berlebihan.

Radikal bebas juga berasal dari sumber eksogen yang dapat terbentuk karena polutan lingkungan, kurang olahraga, pola makan yang tidak sehat, stres, merokok, radiasi sinar ultraviolet, ozon, pelarut sintetis, dan segala aktivitas yang menghasilkan pembakaran. Selain itu, manusia juga memerlukan antioksidan eksogen yang berasal dari luar tubuh untuk mengatasi kerusakan akibat radikal bebas. Senyawa antioksidan mampu melindungi tubuh dari berbagai penyakit yang terkait keberadaan radikal bebas dan dapat meningkatkan kekebalan tubuh. Oleh karena itu konsumsi antioksidan dalam jumlah yang cukup dan teratur dapat menurunkan risiko penyakit degeneratif serta kardiovaskuler, seperti kanker, diabetes melitus, dan aterosklerosis. Konsumsi makanan yang mengandung antioksidan dapat menghambat munculnya penyakit degeneratif akibat penuaan dan meningkatkan status imunologis. Kecukupan asupan antioksidan secara optimal perlu untuk semua kelompok umur.

Komponen antioksidan banyak terdapat pada sayur-sayuran dan buahbuahan. Salah satu kandungan antioksidan yang paling banyak ditemukan adalah vitamin C. Buah Jambu biji memiliki kadar viamin $\mathrm{C}$ yang paling tinggi dibandingkan dengan buah lainnya yaitu $87 \mathrm{mg} / 100$ gram. Kandungan vitamin Buah Jambu biji mencapai puncaknya saat menjelang matang. Hal ini menyebabkan adanya perbedaan kadar vitamin $\mathrm{C}$ maupun bahan kimia lainnya. Berdasarkan analisis mutu kimia tahun 1991 oleh staf peneliti Badan Penelitian Pasar Minggu, diperoleh data bahwa kandungan vitamin $\mathrm{C}$ per 100 gram Buah Jambu biji matang adalah 150,50 mg, matang optimal sebanyak $130,13 \mathrm{mg}$, dan lewat matang sebanyak 132,24 mg 
Berdasarkan sumber yang diperoleh dari Direktorat Gizi Departemen Kesehatan RI (1981), kandungan gizi yang terdapat dalam $100 \mathrm{~g}$ Buah Jambu biji adalah air 86,10 $\mathrm{g}$, energi $49 \mathrm{kkal}$, protein $0,90 \mathrm{~g}$, lemak total 0,30 g, karbohidrat 12,20 g, kalsium $14 \mathrm{mg}$, besi $1,10 \mathrm{mg}$, magnesium $10 \mathrm{mg}$, fosfor 28 $\mathrm{mg}$, kalium $284 \mathrm{mg}$, natrium $3 \mathrm{mg}$, tiamin $0,05 \mathrm{mg}$, riboflavin $0,05 \mathrm{mg}$, niasin $1,2 \mathrm{mg}$, asam panthothenat $0,15 \mathrm{mg}$, vitamin $\mathrm{C} 87$ $\mathrm{mg}$, vitamin B-6 0,143 mg, folat $14 \mathrm{mcg}$, vitamin A $792 \mathrm{IU}$, dan vitamin E 1,2 mgATE.

Vitamin $\mathrm{C}$ adalah salah satu zat gizi yang berperan sebagai antioksidan efektif atau mengatasi radikal bebas yang dapat merusak sel atau jaringan termasuk melindungi lensa dari kerusakan oksidatif yang ditimbulkan oleh radiasi. Vitamin $\mathrm{C}$ berbentuk kristal putih, merupakan suatu asam organik dan termasauk asam, tetapi tidak berbau dalam larutan. Vitamin $\mathrm{C}$ mudah rusak karena oksidasi oleh oksigen dari udara dan juga karena suhu, tetapi lebih stabil bila terdapat dalam bentuk kristal (Wardani, L.A.,2012)

Setiawan, dkk (2009) melakukan penelitiantentang penentuan kadar vitamin $\mathrm{C}$ dalam Buah Jambu biji merahdengan perbandingan tingkat kematangan. Metode yang digunakan adalah metode Iodimetri. Hasil yang diperoleh pada Buah Jambu biji merah yang matang adalah 56,3266 mg sedangkan pada Buah Jambu biji merah setengah matang hanya $38,3 \mathrm{mg}$. Febrianti, dkk. (2015) juga melakukan penelitian tentang perbandingan aktivitas antioksidan Buah Pepaya (Carica papaya L.) dan Buah Jambu biji merah (Psidium guajava L.). Aktivitas antioksidan yang diuji dilakukan dengan tiga cara yaitu uji kandungan asam askorbat (vitamin C), uji total fenol, dan uji penangkapan radikal DPPH menggunakan spektrofotometri UV-Vis. Untuk uji kandungan asam askorbat (vitamin C) dilakukan dengan metode Iodimetri. Hasil penelitian menunjukkan bahwa terdapat perbedaan kandungan asam askorbat (vitamin C) pada Buah Pepaya dan Buah Jambu biji merah berturut - turut yaitu 48,4 $\mathrm{mg} / 100 \mathrm{~g}$ dan 49,86 mg/ 100g.

Berdasarkan hasil penelitian tersebut, peneliti tertarik untuk melakukan penelitian dengan judul "Penetapan Kadar Vitamin C pada Buah Jambu biji merah mentah (Psidium guajava L.) dengan Metode Titrasi Na-2,6 dichlorophenol indophenol (DCIP)".

Berdasarkan latar belakang yang telah diuraikan di atas, adapun rumusan masalah yang ingin diangkat oleh penulis adalah berapa kadar vitamin $\mathrm{C}$ pada Buah Jambu biji merah (Psidium guajava L.) dengan Metode Titrasi Na-2,6 dichlorophenol indophenol (DCIP) ?

Tujuan penelitian ini adalah untuk mengetahui kadar vitamin $\mathrm{C}$ yang terkandung dalam Buah Jambu biji merah (Psidium guajava L.) dengan Metode Titrasi Na-2,6 dichlorophenol indophenol (DCIP)

\section{METODE DAN BAHAN \\ Jenis Penelitian}

Jenis penelitian yang digunakan dalam penelitian ini adalah eksperimen.

\section{Waktu dan Tempat Penelitian}

Penelitian ini dilakukan di Laboratorium Kimia Analisis Farmasi Akademi Farmasi Toraja pada bulan April Mei 2017

\section{Pengambilan Sampel}

Pengambilan sampel diambil langsung di daerah Tallunglipu, Kecamatan Tallunglipu, Kab. Toraja Utara, Sulawesi Selatan.

\section{Alat dan Bahan}

Alat yang digunakan adalah berupa alat-alat gelas dan buret. Sedangkan bahanbahan yang digunakan adalah asam askorbat, asam asetat glasial, asam metafosfat, asam oksalat $0,4 \% \mathrm{~b} / \mathrm{v}$, besi (II) sulfat $2 \mathrm{~N}$, buah jambu biji merah, natrium hidroksida, Na-2,6 dichlorophenol indophenol (DCIP) dan tembaga (II) sulfat $5 \% \mathrm{~b} / \mathrm{v}$

\section{Prosedur Kerja \\ Penyiapan larutan sampel}

Sampel buah jambu biji dibersihkan, lalu ditimbang sebanyak 20 gram, dipotong kecil-kecil lalu diblender dan diencerkan dengan $50 \mathrm{ml}$ asam oksalat kemudian disaring kedalam corong gelas dengan menggunakan kertas saring. Dipipet masingmasing $2 \mathrm{ml}$ larutan yang diperoleh ke dalam tabung reaksi (Tabung I, II, dan III). 


\section{Identifikasi sampel}

Masing-masing

tabung

ditambahkan dengan pereaksi yang berbedabeda. Untuk tabung I sampel ditambahkan 3 tetes larutan pereaksi tembaga (II) sulfat $5 \%$ $\mathrm{b} / \mathrm{v}$ dan 3 tetes larutan $\mathrm{NaOH} 0,1 \mathrm{~N}$. Untuk tabung II sampel ditambahkan 3 tetes larutan $\mathrm{NaOH} 0,1 \mathrm{~N}$ dan 2 tetes pereaksi besi (II) sulfat. Dan untuk tabung III sampel ditambahkan 3 tetes pereaksi Na-2,6 diklorofenol Indofenol (DCIP).

\section{Analisis Kuantitatif}

\section{a. Pembuatan pereaksi}

1. Larutan Na-2,6 diklorofenol Indofenol (DCIP)

Dibuat larutan Na-2,6 diklorofenol Indofenol (DCIP) sebanyak $50 \mathrm{mg}$ ditambahkan $50 \mathrm{ml}$ larutan $\mathrm{NaHCO}_{3} 0,84 \%$ (b/v) dalam $200 \mathrm{ml}$ air suling kemudian disaring.

2. Larutan asam metafosfat-asetat Dibuat larutan asam metafosfat $P$ sebnyak dalam $40 \mathrm{ml}$ asam asetat glasial $\mathrm{P}$ dan encerkan dengan air secukupnya hingga $500 \mathrm{ml}$. Simpan di tempat dingin, hanya boleh digunakan dalam jangka waktu 2 hari (Farmakope Indonesia Edisi IV).

b. Perhitungan kesetaraan pentiter Na2,6 diklorofenol Indofenol (DCIP)

Ditimbang seksama $50 \mathrm{mg}$ asam askorbat BPFI, pindahkan ke dalam labu tentukur $100 \mathrm{ml}$, kemudian dilarutkan dengan larutan asam metafosfat-asetat LP, dicukupkan sampai garis tanda. Dipipet $1 \mathrm{ml}$, dimasukkan ke dalam erlenmeyer dan ditambahkan larutan asam metafosfatasetat $6 \mathrm{ml}$. Titrasi segera dengan larutan 2,6-diklorofenol indofenol hingga warna merah muda mantap tidak kurang dari 5 detik. Lakukan titrasi blanko menggunakan $7 \mathrm{ml}$ asam metafosfatasetat dan dititrasi dengan larutan 2,6diklorofenol indofenol hingga warna merah muda mantap. Kadar larutan baku 2,6-diklorofenol indofenol dinyatakan dengan kesetaraan dalam $\mathrm{mg}$ asam askorbat (Ditjen POM, 1995). Perhitungan kesetaraan dihitung dengan rumus :
Kesetaraan $(\mathrm{mg})=\frac{\mathrm{Va} \times \mathrm{W} \text { x \% Kadar }}{\mathrm{Vc} \times(\mathrm{Vt}-\mathrm{Vb})}$

Keterangan :

$\mathrm{Va}=$ Volume aliquot $(\mathrm{ml})$

$\mathrm{W}=$ Berat vitamin C $(\mathrm{mg})$

$\mathrm{Vt}=$ Volume titrasi $(\mathrm{ml})$

$\mathrm{Vb}=$ Volume blanko $(\mathrm{ml})$

$\mathrm{Vc}=$ Volume labu tentukur (ml)

\section{c. Penyiapan larutan sampel}

Sampel di bersihkan, ditimbang sekitar $25 \mathrm{~g}$ lalu di potong kecil-kecil dimasukkan ke dalam blender kemudian ditambah sekitar $5 \mathrm{~g}$ asam metafosfatasetat dimasukkan dalam blender, setelah itu di blender,kemudian ditimbang seksama 2,5 g lalu dimasukkan kedalam labu tentukur 25 $\mathrm{ml}$ dan ditambahkan asam metafosfatasetat sampai garis tanda. Dihomogenkan, kemudian disaring Filtrat pertama dibuang $\pm 5 \mathrm{ml}$. (Ditjen POM, 1995).

\section{d. Penetapan kadar vitamin C}

Dipipet $2 \mathrm{ml}$ larutan sampel lalu dimasukkan ke dalam erlenmeyer kemudian ditambah $5 \mathrm{ml}$ asam metafosfat-asetat. Dititrasi dengan larutan 2,6-diklorofenol indofenol sampai terbentuk warna merah jambu yang mantap sebagai titik akhir titrasi. Dilakukan penetapan blanko (Ditjen POM, 1995). Menurut AOAC (2002), kadar vitamin $\mathrm{C}$ dapat dihitung dengan rumus :

$$
\begin{aligned}
& \text { Kadar vitamin C }\left(\frac{\mathrm{mg}}{\mathrm{g}}\right) \\
& =\frac{(V t-V b) x \text { Kesetaraan } x V l}{V p \times \mathrm{Bs}}
\end{aligned}
$$

Keterangan :

$\mathrm{Vt}$ : Volume titrasi (ml)

$\mathrm{Vb}$ : Volume blanko (ml)

$\mathrm{Vl}$ : Volume labu tentukur (ml)

Vp : Volume pemipetan (ml)

Bs : Berat sampel $(\mathrm{g})$

\section{HASIL DAN PEMBAHASAN}

Pada penelitian ini dilakukan analisis kualitatif kandungan vitamin $\mathrm{C}$ pada Buah Jambu biji merah dengan variasi tingkat kematangan buah yang berbeda yaitu Buah Jambu biji merah yang mentah, setengah matang dan matang. Adapun hasil analisis 
kualitatif kandungan vitamin C pada Buah Jambu biji merah dapat dilihat pada Tabel 1.

Tabel 1. Hasil analasis kualitatif sampel Jambu biji merah (Psidium guajava L.)

\begin{tabular}{|c|c|c|c|c|}
\hline Sampel & & $\begin{array}{c}\text { Pereaksi } \\
\text { A }\end{array}$ & $\begin{array}{c}\text { Pereaksi } \\
\text { B }\end{array}$ & $\begin{array}{c}\text { Pereaksi } \\
\text { C }\end{array}$ \\
\hline \multirow{3}{*}{$\begin{array}{c}\text { Jambu } \\
\text { biji } \\
\text { mentah }\end{array}$} & I & $\begin{array}{l}\text { Biru } \\
\text { ungu }\end{array}$ & - & \multirow[b]{3}{*}{$\begin{array}{l}\text { merah } \\
\text { muda } \\
\text { langsung } \\
\text { menhilang }\end{array}$} \\
\hline & II & - & $\begin{array}{l}\text { Ungu tua } \\
\text { bening }\end{array}$ & \\
\hline & III & - & - & \\
\hline \multirow{3}{*}{$\begin{array}{c}\text { Jambu } \\
\text { biji } \\
\text { setengah } \\
\text { matang }\end{array}$} & I & Biru & - & \multirow{3}{*}{$\begin{array}{l}\text { merah } \\
\text { muda } \\
\text { hampir } \\
\text { bening }\end{array}$} \\
\hline & II & - & $\begin{array}{l}\text { Ungu } \\
\text { keruh }\end{array}$ & \\
\hline & III & - & - & \\
\hline \multirow{3}{*}{$\begin{array}{c}\text { Jambu } \\
\text { biji } \\
\text { matang }\end{array}$} & I & $\begin{array}{c}\text { Biru } \\
\text { khijauan }\end{array}$ & - & \\
\hline & II & - & $\begin{array}{l}\text { Ungu } \\
\text { keruh }\end{array}$ & \\
\hline & III & - & - & $\begin{array}{c}\text { Merah } \\
\text { muda }\end{array}$ \\
\hline
\end{tabular}

Keterangan :

Pereaksi $\mathrm{A}=$ pereaksi tembaga (II) sulfat $5 \% \mathrm{~b} / \mathrm{v}$ dan 3 tetes larutan $\mathrm{NaOH} 0,1 \mathrm{~N}$

Pereaksi $\mathrm{B}=3$ tetes larutan $\mathrm{NaOH} 0,1 \mathrm{~N}$ dan 2 tetes pereaksi besi (II) sulfat

Pereaksi $\mathrm{C}=3$ tetes pereaksi Na-2,6 diklorofenol Indofenol (DCIP)

Berdasarkan data dari tabel 1 diperoleh bahwa sampel Buah Jambu biji merah mentah mengandung vitamin $\mathrm{C}$ dengan hasil yang telah sesuai dibandingkan dengan Jambu biji merah setengah matang dan matang. Hal ini dapat dilihat dari hasil reaksi warna yang terbentuk. Hasil reaksi warna yang terbentuk adalah pada sampel Jambu biji merah mentah yang ditambahkan pereaksi A diperoleh warna biru keunguan yang bening, sedangkan pada sampel Jambu biji merah setengah matang dan matang yang ditambahkan pereaksi A diperoleh warna biru keruh. Reaksi yang terjadi adalah
$\mathrm{C}_{6} \mathrm{H}_{8} \mathrm{O}_{6}+\mathrm{CuSO}_{4} .5 \mathrm{H}_{2} \mathrm{O}+\mathrm{NaOH} \rightarrow \mathrm{Na}_{2} \mathrm{SO}_{4}+\mathrm{C}_{6} \mathrm{H}_{12} \mathrm{O}_{6}+\mathrm{Cu}_{2} \mathrm{O}+\mathrm{H}_{2} \mathrm{O}$

Pada sampel Jambu biji merah mentah yang ditambahkan pereaksi B diperoleh warna ungu yang bening, sedangkan pada sampel Jambu biji merah setengah matang dan matang diperoleh warna ungu yang keruh. Reaksi yang terjadi adalah $\mathrm{C}_{6} \mathrm{H}_{8} \mathrm{O}_{6}+\mathrm{FeSO}_{4} .5 \mathrm{H}_{2} \mathrm{O}+\mathrm{NaOH} \rightarrow \mathrm{Na}_{2} \mathrm{SO}_{4}+\mathrm{C}_{6} \mathrm{H}_{12} \mathrm{O}_{6}+\mathrm{Fe}_{2} \mathrm{O}+\mathrm{H}_{2} \mathrm{O}$

Pada sampel Jambu biji merah mentah yang ditambahkan pereaksi $\mathrm{C}$ terjadi perubahan warna dari jernih menjadi merah, akan tetapi setelah beberapa detik warna merah pada sampel kembali jernih. Sedangkan pada sampel Jambu biji merah setengah matang dan matang yang ditambahkan pereaksi $\mathrm{C}$ terjadi perubahan warna dari keruh menjadi merah, akan tetapi setelah beberapa menit warna merah pada larutan sampel mulai memudar. Reaksi yang terjadi adalah

$\mathrm{C}_{6} \mathrm{H}_{8} \mathrm{O}_{6}+\mathrm{C}_{12} \mathrm{H}_{7} \mathrm{NCl}_{2} \mathrm{O}_{2} \rightarrow \mathrm{C}_{6} \mathrm{H}_{6} \mathrm{O}_{6}+\mathrm{C}_{12} \mathrm{H}_{9} \mathrm{NCl}_{2} \mathrm{O}_{2}$

Vitamin $\mathrm{C}$ merupakan asam kuat dengan nilai pKa 4,21 yang bersifat sangat sensitif terhadap pengaruh-pengaruh luar yang menyebabkan kerusakan seperti suhu, oksigen, enzim, kadar air, dan katalisator logam. Asam askorbat sangat mudah teroksidasi menjadi Ldehidroaskorbat yang masih mempunyai keaktivan sebagai vitamin C. Asam Ldehidroaskorbat secara kimia sangat labil dan dapat mengalami perubahan lebih lanjut menjadi asam L-diketogulonat yang tidak memiliki keaktivan vitamin $\mathrm{C}$ lagi.

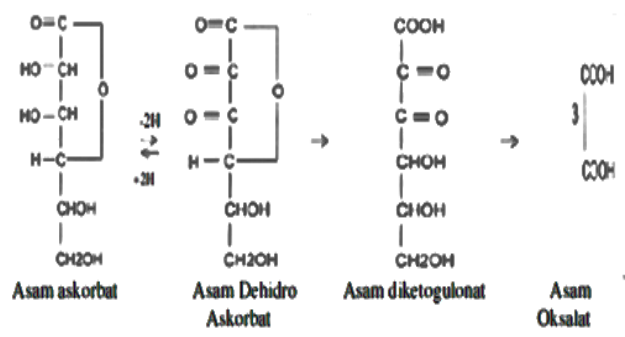

Gambar 1 Reaksi oksidasi vitamin C (Putra,2011)

Adanya penambahan pereaksi tembaga (II) sulfat menyebabkan vitamin $\mathrm{C}$ mereduksi ion $\mathrm{Cu}^{2+}$ menjadi ion $\mathrm{Cu}^{+}$sehingga terjadi perubahan warna dari sampel Jambu biji merah yang berwarna bening menjadi biru keunguan. Pada sampel Jambu biji setengah matang dan matang tidak diperoleh warna biru keunguan yang disebabkan oleh warna larutan sampel yang keruh meskipun 
telah disaring sebanyak dua kali sehingga perubahan warna yang dihasilkan hanya berwarna biru pucat. Vitamin $\mathrm{C}$ bersifat asam yang larut dalam pelarut polar, sehingga untuk hasil yang terbaik digunakan $\mathrm{NaOH}$ yang bersifat basa. Alasan penambahan $\mathrm{NaOH}$ adalah untuk mempercepat terjadinya reaksi antara sampel dan pelarut. Penambahan pereaksi besi (II) sulfat digunakan sebagai pengoksidasi vitamin $\mathrm{C}$ sehingga terjadi perubahan warna ungu. Pada sampel Jambu biji merah setengah matang dan matang tidak diperoleh warna ungu yang disebabkan oleh warna larutan sampel yang keruh sehingga perubahan yang dihasilkan hanya berwarna ungu pucat. Larutan pereaksi $\mathrm{Na}-2,6$ diklorofenol Indofenol (DCIP) menyebabkan hilangnya warna terhadap larutan sampel. Apabila Na-2,6 diklorofenol Indofenol (DI) direduksi oleh vitamin C maka larutan akan menjadi tidak berwarna, dan apabila semua vitamin $\mathrm{C}$ sudah mereduksi $\mathrm{Na}-2,6$ diklorofenol Indofenol (DI) maka akan terjadi pewarnaan.

Berdasarkan penelitian analisis kualitatif pada Jambu biji merah matang, setengah matang, dan mentah dengan pereaksi A, pereaksi $\mathrm{B}$, dan pereaksi $\mathrm{C}$ diperoleh hasil bahwa Buah Jambu biji merah positif mengandung vitamin C. Selanjutnya dilakukan penelitian analisis kuantitatif pada Buah Jambu biji merah mentah yang memiliki hasil lebih bagus dengan metode titrasi menggunakan $\mathrm{Na}-2,6$ diklorofenol Indofenol (DCIP).

Tabel 2 Hasil Kesetaraan larutan Na-2,6 diklorofenol Indofenol dengan vitamin $\mathrm{C}$ standar

\begin{tabular}{|c|c|c|c|c|c|}
\hline \multirow{2}{*}{$\begin{array}{c}\text { W } \\
\text { vit. } \\
\text { C } \\
(\mathrm{mg})\end{array}$} & \multirow{2}{*}{$\begin{array}{c}\mathrm{V} \\
(\mathrm{ml})\end{array}$} & \multicolumn{3}{|c|}{$\begin{array}{c}\text { Volume } \\
\text { diklorofenol } \\
\text { Indofenol }(\mathrm{ml})\end{array}$} & \multirow[t]{2}{*}{$\begin{array}{l}\text { Keseta } \\
\text { aan } \\
(\mathrm{mg})\end{array}$} \\
\hline & & $\mathrm{V}_{1}$ & $\mathrm{~V}_{2}$ & $\begin{array}{c}\mathrm{V}_{\text {rata- }} \\
\text { rata }\end{array}$ & \\
\hline 50 & 7 & 12 & 15 & 13,5 & 0,4045 \\
\hline 50 & 7 & 13 & 15 & 14 & 0,429 \\
\hline 50 & 7 & 12 & 14 & 13 & 0,4125 \\
\hline
\end{tabular}

Pada penelitian ini kadar asam askorbat diukur dengan menggunakan metode titrasi Na-2,6 diklorofenol Indofenol. Larutan Na-2,6 diklorofenol Indofenol digunakan sebagai titran dan pada larutan sampel yang ditambahkan asam metafosfat sebagai titer. Larutan DCIP yang digunakan untuk titrasi distandarisasi dengan larutan vitamin $\mathrm{C}$ standar. Vitamin $\mathrm{C}$ standar ditambahkan larutan asam metafosfat-asetat dan dititrasi dengan $\mathrm{Na}-2,6$ diklorofenol Indofenol sampai diperoleh titik akhir titrasi (merah muda mantap). Dan selanjutnya dilakukan titrasi blanko menggunakan larutan asam metafosfat-asetat. Kadar larutan baku 2,6-diklorofenol indofenol dinyatakan dengan kesetaraan dalam mg asam askorbat. Hasil perhitungan kesetaraan yang diperoleh adalah $1 \mathrm{ml}$ 2,6-diklorofenol indofenol setara dengan 0,429 $\mathrm{mg}$ vitamin $\mathrm{C}$.

Sampel Buah Jambu biji merah (Psidium guajava L.) diblender dengan asam metafosfat-asetat kemudian difiltrasi dengan menggunakan kertas saring. Penggunaan asam metafosfat-asetat pada saat sampel diblender bertujuan untuk mencegah logam katalis lain mengoksidasi vitamin $C$. Selanjutnya filtrat dititrasi dengan Na-2,6 dichlorophenol indophenol (DCIP) sampai titik akhir titrasi (merah muda). Dilakukan titrasi blanko menggunakan asam metafosfatasetat dan dititrasi dengan Na-2,6 diklorofenol indofenol.

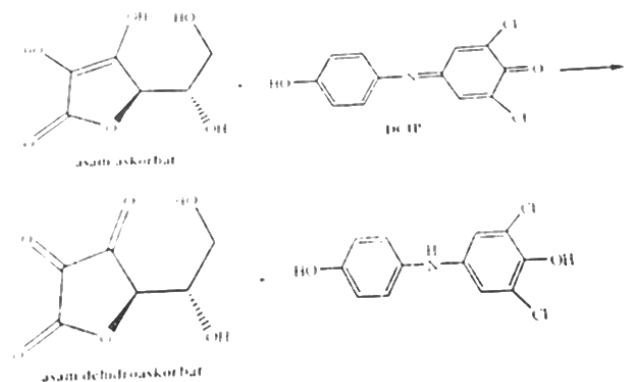

Gambar 2 reaksi yang terjadi pada penetapan kadar asam askorbat dengan metode DCIP

Perhitungan kadar yang diperoleh adalah $0,429 \mathrm{mg}$ atau $42,9 \mathrm{mg} / 100$ gram Buah Jambu biji merah mentah. Hasil yang diperoleh berbeda dengan kandungan vitamin C pada Jambu biji merah (Psidium guajava L.) yaitu $87 \mathrm{mg} / 100$ gram. Perbedaan kandungan asam askorbat pada buah-buahan dapat dipengaruhi oleh berbagai faktor, antara lain varietas, spesies, kultivar, dan kondisi panen. Variabel lain yang berpengaruh adalah suhu lingkungan, proses fotosintesis, kelembaban relatif, stres oksidatif, paparan matahari. Polutan juga dianggap sebagai kontributor utama yang mempengaruhi variasi kandungan asam askorbat. Tingkat kematangan buah 
mempengaruhi banyaknya kadar vitamin C pada buah. Semakin matang buah maka semakin tinggi kadar asam askorbatnya. Hal ini disebabkan karena selama proses pemasakan buah mengalami peningkatan kadar askorbat.

\section{PENUTUP}

\section{Kesimpulan}

Berdasarkan penelitian yang telah dilakukan diperoleh hasil sebagai berikut :

a. Pada analisis kualitatif sampel Jambu biji merah (Psidium guajava L.) mentah, setengah matang, dan matang positif mengandung vitamin $\mathrm{C}$ yang ditandai dengan adanya perubahan warna setelah penambahan larutan pereaksi tembaga (II) sulfat $0,5 \%$ (biru keunguan), besi (II) sulfat $0,2 \mathrm{~N}$ (ungu), larutan $\mathrm{NaOH}$ $0,1 \mathrm{~N}$ dan larutan $\mathrm{Na}-2,6$ dichlorophenol indophenol (DCIP) $0.5 \quad \mathrm{mg} / \mathrm{ml}$ (menghilangkan warna larutan).

b. Pada analisis kuantitatif sampel Jambu biji merah mentah (Psidium guajava L.) dengan metode titrasi dengan Na-2,6 dichlorophenol indophenol (DCIP) diperoleh kadar vitamin $\mathrm{C}$ sebesar 0,429 $\mathrm{mg} / \mathrm{gram}$ atau $0,2145 \mathrm{mg} / \mathrm{g}$.

\section{Saran}

Disarankan kepada masyarakat untuk lebih memilih mengonsumsi buahbuahan segar dibandingkan buah-buahan yang telah diolah karena kandungan antioksidan yang terdapat dalam buah segar sangat mudah teroksidasi setelah mengalami pengolahan.

\section{DAFTAR PUSTAKA}

Agustinus, 2009, Studi Hematologis Potensi Metabolik Jambu Biji Merah (Psidium guajava L.) pada Penderita Demam Berdarah Dengue,Skripsi. Institut Pertanian Bogor, Bogor.

Anonim, 1979, Card System dan Reaksi Warna. Institut Teknologi Bandung

Anonim, 1995, Farmakope Indonesia Edisi ke IV. Departemen Kesehatan. Republik Indonesia.

Anonim, 1979, Farmakope Indonesia Edisi ke III. Departemen Kesehatan. Republik Indonesia
Febrianti, Novi, Rohmana M.I., Yunianto, Irfan., dan Dhaniaputri, Risanti, 2015, Perbandingan Aktivitas Antioksidan buah pepaya (Carica papaya L.) dan buah jambu biji merah (Psidium guajava L). Jurnal [Internet]. [diakses pada 09 Maret 2017]. Tersedia pada : http://researchreport.umm.ac.id/index.php/researchreport/article/download/703/908.

Firmansyah, Erwin, 2014, Analisis Kandungan Vitamin C. Malang : Universitas Brawijaya

Hidayah, N., 2009, Sifat Optik Buah Jambu Biji (Psidium guajava) yang disimpan dalam Toples Plastik Menggunakan Spektrofotometer Reflektans UV-Vis, Skripsi, Institut Teknologi Bogor.

P.S., Rizky, 2011, Peranan Vitamin C dalam Perawatan Kulit. Bandung : Universitas Islam Bandung

Putra, Azhar, 2011, Penetapan Kadar Vitamin C dari Bawang Putih (Allium sativum L) Secara Titrasi 2,6Diklorofenol Indofenol, skripsi,Universitas Sumatra Utara, Medan

S.P., Parimin, 2005, Jambu Biji; Budidaya dan Ragam Manfaatnya. Google Book halaman 11-12[Internet]. [diakses pada 11 Maret 2017]. Tersedia pada : http://books.google.co.id/books?id=y Btep11W3swC\&pg=PA11\&dq=morfo $\underline{\text { logi }+ \text { jambu+biji\&hl=id\&sa }=X \& \text { redir }}$ esc $=y$.

Setiawan, A., Sahudi, dan Mahrozah, W., 2009, Penentuan Kadar Vitamin C Dalam Buah Jambu Biji Merah. Yogyakarta : Akademi Teknologi Kulit

Suprianto, La Ode, 2010, Analisis Kadar Vitamin C pada Buah Jambu Biji Merah (Psidium guajava L.) Berdasarkan Suhu Penyimpanan, Thesis, Universitas Muhammadiyah Semarang, Semarang. 